\title{
THE USE OF THE "PROGRESSIVE MUSCLE RELAXATION" TECHNIQUE FOR PAIN RELIEF IN GYNECOLOGY AND OBSTETRICS
}

\author{
Adriana Aparecida Delloiagono de Paula \\ Emilia Campos de Carvalho ${ }^{2}$ \\ Claudia Benedita dos Santos ${ }^{3}$
}

Paula AAD, Carvalho EC, Santos CB. The use of the "progressive muscle relaxation" technique for pain relief in gynecology and obstetrics. Rev Latino-am Enfermagem 2002 setembro-outubro; 10(5):654-9.

Pain is one of the most frequent symptoms observed in patients and various treatments are proposed for its relief, including relaxation techniques. With the purpose of testing the effect of a specific intervention (progressive muscle relaxation) in a determined situation (pain), this study aimed at verifying the level of pain in post-surgery patients prior to and after the application of the Progressive Muscle Relaxation technique. The subjects, 61 patients, had been submitted to abdominal surgical interventions, of which $52.5 \%$ had a gynecological nature and $47.5 \%$ obstetrical. Our data showed statistically significant alterations in life parameters as well as muscular alterations after the application of the Progressive Muscle Relaxation technique. It was concluded that the use of the Progressive Muscle Relaxation Technique enabled the subjects to determine that their pain levels decreased.

\section{EL USO de LA estrategia “RELAJAMIENTO MUSCULAR PROgResivo" PARA ALIVIO DEL DOLOR}

El dolor es uno de los más frecuentes síntomas observados en pacientes. Varios son los tratamientos propuestos para alivio, incluyéndose las técnicas de relajamiento progresivo muscular. Con el propósito de probar el efecto de una intervención específica (relajamiento muscular progresivo) en determinada situación (dolor), tuvimos como objetivo en el presente estudio, verificar el nivel de dolor en pacientes post-quirúrgicos antes y después de la aplicación de la técnica de Relajamiento Muscular Progresivo. Se registraron como sujetos 61 pacientes que se sometieron a intervención quirúrgica abdominal, siendo 52.5\% de naturaleza ginecológica y $47.5 \%$ obstétrica. Los datos demostraron alteraciones estadísticamente significativas de parámetros vitales y alteraciones musculares después de la aplicación de la técnica de Relajamiento Muscular Progresivo. Concluimos que el uso de la técnica de relajamiento empleada permitió a los sujetos evaluar que su nivel de dolor disminuyó.

\section{O Uso da estratégia de “Relaxamento muscular progressivo” PARA ALÍVIO DA DOR}

Dor é um dos mais freqüentes sintomas observados em pacientes. Vários são os tratamentos propostos para o seu alívio, incluindo-se as técnicas de relaxamento muscular progressivo. Com o propósito de testar o efeito de uma intervenção específica (relaxamento) em uma determinada situação (dor) tivemos como objetivo no presente estudo verificar o nível de dor em pacientes pós-cirúrgicos antes e após a aplicação da técnica de Relaxamento Muscular Progressivo. Foram sujeitos 61 pacientes que se submeteram à intervenção cirúrgica abdominal, sendo 52,5\% de natureza ginecológica e 47,5\% obstétrica. Nossos dados demonstraram alterações estatisticamente significantes de parâmetros vitais e alterações musculares, após aplicação da técnica de Relaxamento Muscular Progressivo. Concluímos que o uso da técnica de relaxamento empregada permitiu aos sujeitos avaliar que seu nível de dor diminuiu.

DESCRITORES: dor, relaxamento, assistência na fase pós-operatória

\footnotetext{
${ }^{1}$ RN, Graduate Student in the Doctoral Program in Fundamental Nursing; ${ }^{2}$ RN, PhD, Full Professor, e-mail: ecdcava@eerp.usp.br; ${ }^{3}$ BS, MS, PhD, Professor, e-mail: cbsantos@eerp.usp.br. University of São Paulo at Ribeirão Preto College of Nursing - WHO Collaborating Centre for Nursing Research Development, Brazil
} 


\section{INTRODUCTION}

$\boldsymbol{P}_{\text {ain }}$ is the most frequent symptom which leads a patient to seek medical help. In most cases, it is the symptom of a disease, the treatment of which promotes its resolution. In some patients, however, pain is not a symptom, but a sequel of a disease that has already been cured. In these cases, pain control becomes even more important, since it indicates life quality and the possibility of reintegrating the patient to his professional and social activities $^{(1)}$.

Pain is defined by each one of us according to our personal experiences and involves a variety of feelings, sensations and situations.

The communication of a patient's painful experience to the health care professionals assisting him is fundamental for the understanding of such condition, implementation of analgesic measures and evaluation of therapeutic efficacy, since pain is an individual and subjective phenomenon ${ }^{(2)}$. It is also considered to be any type of physical damage that is reported to be felt by a patient at the time when he claims to feel it ${ }^{(3)}$.

This conception understands that the only individual who is able to define a person's pain is the one who is feeling it. Therefore, nurses must believe the patient and try to identify the various behaviors that indicate not only the presence or feeling of pain, but also everything that is experienced by the patient in relation to it. They should also understand that efficient pain treatment requires knowledge concerning the physiological and cultural aspects of each individual.

Experiencing stimuli which lead to stress, nursing professionals have made efforts to help individuals in the evaluation and control of their own reactions, for which there are strategies that use physiological, cognitive and behavioral techniques. Among them are the relaxation techniques.

Relaxation must be attempted in order to reduce pain or pain perception, reduce tension, create a pleasant affective condition, reduce anticipating anxiety, reduce anxiety as a response to stress, increase parasympathetic activities, increase knowledge concerning muscle tension and autonomous stimuli, improve concentration, increase the feeling of control, improve the ability to block inner talk, energize and improve sleep, increase suggestability, decrease the cardiac index, lower pressure, warm or cool body parts, enhance performance of physical activities and help in the relationship with others ${ }^{(4)}$.
Various relaxation techniques have been used and their effects upon pain and stress have been described in the literature. Their benefits can be pointed out as follows: post-operative period resulting in improved comfort level of patients ${ }^{(5)}$; decrease in abdominal muscle tension, reduction of distress caused by painful sensations ${ }^{(6)}$; reduction in the incidence of psychiatric reactions occurring postoperatively ${ }^{(7)}$; decrease in anxiety and depression levels and increase in the self-esteem of young mothers during the first postpartum weeks ${ }^{(8-9)}$.

Among the relaxation techniques, we emphasize that of Progressive Muscle Relaxation, which is used in this study. It is mainly based on the premise that anxiety and relaxation are excluding situations ${ }^{(10)}$. The procedures used are simple: the individual retracts a specific set of muscles as much as possible and experiences as tension sensation. The muscles are then relaxed as much as possible and the individual focuses on the relaxation sensations. It is, therefore, a participant exercise in which the individual himself seeks a state of relaxation and physical well-being.

The benefit arising from the practice of Progressive Muscle Relaxation is that it sensitizes individuals to recognize the increase in muscle tension ${ }^{(11)}$. Muscle tension increases are signs of an increase in stress reaction. When Progressive Muscle Relaxation is practiced and incorporated to the individual's life style, it can help to neutralize some of the effects of stress reaction. Considering that this technique could reduce pain, we conducted this study aiming at verifying pain levels in gynecology and obstetrics post-surgery patients before and after the application of the Progressive Muscle Relaxation technique.

\section{METHODOLOGY}

This study involves a specific intervention (relaxation) and the comparison of qualitative and quantitative variables concerning a determined situation (pain) before and after an intervention. This type of research is qualified as quasi-experimental and involves the manipulation of an independent variable; however, it lacks randomization and a control group ${ }^{(12)}$.

In this study, the manipulated variable was the Progressive Muscle Relaxation and each subject was its own control in the situations prior to and after the application of such Relaxation. 
A period of time of one month was established for data collection from the moment when the research project was evaluated and approved of by the Research Ethics Committee of the location where the study was conducted and the requirements for the performance of studies involving human beings were met. Each patient was informed with regard to the purpose of the research and his formal agreement to participate in the study was requested. After the patient's free and informed consent had been obtained, the observance of the inclusion criteria and the application of the other instruments and techniques utilized in the research were commenced.

The study was carried out in a gynecology and obstetrics hospitalization unit of a large public university hospital in the interior of São Paulo State, Brazil.

The sample consisted of 61 patients who had been submitted to abdominal surgery in the gynecology and obstetrics unit and who met the following inclusion criteria: agreed to participate in the study; were over 18 years old; presented a level of pain that differed from zero, according to the analogical scale; were able to keep logical conversation; and were able to discriminate visually the different images of the analogical visual scale. We point out that secrecy concerning the subjects' identification was kept.

Data collection was initially carried out by means of the registration of data obtained from the patients, for which end an observation instrument was used. This instrument consisted of information regarding the patient's identification (age, origin, occupation, level of education, type of pain, type of surgery to which they had been submitted) and physiological pain indicators, such as vital signs (arterial pressure, arterial pulse rate, respiration and temperature), muscle manifestations (muscle tension in the jawbones, forearms, fist, head and back), pain resulting from a discreet skin pinch and perspiration. These data were initially observed in the pre-relaxation situation. Following, the Progressive Muscle Relaxation technique was applied based on the description made in literature (13) $^{(13)}$ with a few alterations. After the relaxation, the mentioned parameters were evaluated. Later, identification of the pain level was attained by means of Huskisson's analogical visual scale.

\section{RESULTS AND DISCUSSION}

The characterization of the sample as to age, origin, occupation, education level and the surgery to which the patients had been submitted as well as the characterization descriptors of the patients' post-surgical pain are presented in Table 1.

Table 1 - Distribution of the 61 patients according to the variables age, origin, occupation, level of education, type of surgery and characterization descriptors of patients' post-surgical pain

\begin{tabular}{|c|c|c|}
\hline Variable & Indicator & Frequency $\%$ \\
\hline \multirow[t]{3}{*}{ Age } & $17 \& 37$ years & 55.8 \\
\hline & $37 \& 57$ years & 34.4 \\
\hline & $\geq 57$ years & 9.80 \\
\hline \multirow[t]{2}{*}{ Origin } & Ribeirão Preto-SP, Brazil & 73.7 \\
\hline & Other locations & 26.3 \\
\hline \multirow[t]{2}{*}{ Occupation } & Unqualified & 86.8 \\
\hline & Qualified & 13.2 \\
\hline \multirow[t]{3}{*}{ Education } & Education: illiterate + Incomplete Elementary School & 65.6 \\
\hline & Complete Elem. School + Incomplete High School & 19.6 \\
\hline & Complete High School + Complete College Major & 14.8 \\
\hline \multirow[t]{3}{*}{ Surgery } & Obstetric (cesarean section) & 47.5 \\
\hline & Gynecological & 52.5 \\
\hline & Strong & 77.0 \\
\hline \multirow[t]{2}{*}{ Pain } & Needle-prick like & 11.6 \\
\hline & Others & 11.4 \\
\hline
\end{tabular}

Most of the subjects (55.8\%) were aged 17 to 36 years, an age range which is considered as the most socially productive. As to origin, we observed a high incidence $(73.7 \%)$ of patients from the city where the institution under study is located. The patients' occupation was classified according to the categories observed in the literature ${ }^{(14)}$ and 53 patients ( $86.8 \%$ ) presented unqualified occupations, among which "homemaking" activities predominated $(77 \%)$. Regarding education level ${ }^{*(15)}$, we found a larger incidence (65.6\%) of patients with low educational level (illiterate or with incomplete elementary education). In relation to the type of surgery performed, all the patients in our sample had been submitted to abdominal surgery, of which $52.5 \%$ had been gynecological (abdominal hysterectomy, oophorectomy, salpingectomy, myomectomy, Burch, tubal occlusion, laparotomy, laparoscopy and Wertheim Meigs) and $47.5 \%$ obstetric surgeries (cesarean sections).

Considering that pain is a subjective experience,

\footnotetext{
* In Brazil, according to the new Education Law, the education model consists of basic education (comprising pre-school, elementary school (8 years) and high school (3 years) and higher education (4 to 6 years), depending on the field $)^{(9)}$.
} 
one of our priorities for an adequate treatment was a pain evaluation (its quality or character). As to the exact pain site, we obtained $100 \%$ of responses as being in the site of the surgery. Concerning the pain type, we found descriptors that were confirmed in studies ${ }^{(16)}$ with the purpose to analyze the language used by nurses in the characterization of post-surgery pain based on the pain questionnaire by McGill. Among the participants in our study, the most frequent descriptor was strong pain (77\%).

When we questioned the subjects as to the procedure usually taken in order to relieve and/or eliminate pain, we found $100 \%$ of replies stating that they called nurses to administrate medication and only 3 patients $(5 \%)$ informed that before they called the nurse they tried remaining still.

These data are in accordance with those in studies $^{(17)}$ in which it was found that many nursing actions related to pain relief were almost exclusively dependent on a medical procedure, without a specific evaluation being made by the nurse. However, we agree with authors ${ }^{(18)}$ as to their affirmation that pain reduction can be more effective when this procedure is associated with other techniques for pain relief. Of the 61 observed patients, it was not possible to assert that pain level reduction in post-relaxation was not exclusively due to the technique in $9(14.7 \%)$ of them, since they were also under the effect of analgesia. In these cases, the analgesic drugs were used in periods that were shorter than 6:00 hours However, pain reduction in $52(85.3 \%)$ of the patients resulted from the use of the technique.

We performed an analysis of vital signs in the pre- and post- relaxation situations based on parametric tests (paired t test) and on non-parametric tests (Sign Test, McNemar for change significance and $\left.\chi^{2}\right)^{(19-22)}$. All the tests were carried out with a level of significance established in $\alpha=0.05$. Such data are contained in Table 2 .

Table 2 - Mean values of vital signs (Systolic Pressure; Diastolic Pressure; Arterial Pulse; Respiration and Temperature) and their respective standard deviances in the pre- and post- relaxation phases, differences between the averages of such parameters and conclusions based on statistical tests

\begin{tabular}{|c|c|c|c|c|c|c|c|c|}
\hline \multirow[t]{2}{*}{ Variable } & \multicolumn{2}{|c|}{ Pre - Relaxation } & \multicolumn{2}{|c|}{ Post - Relaxation } & \multirow{2}{*}{$\begin{array}{l}\text { Difference } \\
\text { between the } \\
\text { two averages } \\
\text { (Pre - Post) }\end{array}$} & \multirow{2}{*}{$\begin{array}{l}\text { Standard } \\
\text { Deviance } \\
\text { of the } \\
\text { difference }\end{array}$} & \multirow[t]{2}{*}{ Test } & \multirow[t]{2}{*}{ Conclusion } \\
\hline & Average & St. Dev. & Average & St. Dev. & & & & \\
\hline Systolic Pressure & 135.08 & 13.24 & 120.32 & 12.24 & 14.75 & 7.21 & 15.97661 & $p<0.05^{*}$ \\
\hline Diastolic Pressure & 85.29 & 11.60 & 71.96 & 9.96 & 10.32 & 6.31 & 12.77144 & $p<0.05^{\star}$ \\
\hline Respiration & 25.19 & 4.99 & 22.11 & 4.96 & 3.08 & 1.40 & 17.12160 & $p<0.05^{*}$ \\
\hline Temperature & 36.84 & 0.34 & 36.50 & 0.32 & 0.34 & 0.13 & 19.68140 & $p<0.05^{*}$ \\
\hline
\end{tabular}

* Statistically significant difference between the averages of the parameters in the pre- and post relaxation phases

According to the previous table, we concluded that the differences found between the pre- and post-relaxation phases are statistically significant for all the variables under study (systolic pressure, diastolic pressure, respiration and temperature). Such data are in accordance with the results obtained in the literature ${ }^{(23)}$, where it was also found that there was a reduction in the physiological indicators concerning arterial pressure, cardiac frequency and respiratory frequency.

We present below the analysis of the data concerning muscle observations in the pre- and postrelaxation situations. To that end, we applied, in the statistical analysis, the McNemar Test and the $\chi^{2}$ test (due to the presence of null frequencies, we used the Binomial Test or McNemar, when the number of changes was smaller than $25 \%$ and the $\chi^{2}$ test in the other cases). Such data is presented in Table 3.
Table 3 - Distribution of the 61 patients according to muscle condition, pain complaint and perspiration in the pre- and post-relaxation phase

\begin{tabular}{lccc}
\hline Variable & Indicator & Pre-Relaxation & Post-Relaxation \\
\hline Tension in the & Relaxed & $47(77 \%)$ & $61(100 \%)$ \\
jawbone muscles & Tight & $14(23 \%)$ & 0 \\
Tension in the & Relaxed & $48(78.7 \%)$ & $61(100 \%)$ \\
forearm muscles & Slightly curved & $13(21.3 \%)$ & 0 \\
Tension in the fist & Relaxed & $54(88.5 \%)$ & $61(100 \%)$ \\
muscles & Almost closed & $07(11.5 \%)$ & 0 \\
Perspiration & Normal & $43(70.5 \%)$ & $61(100 \%)$ \\
& Excessive & $18(29.5 \%)$ & 0 \\
Tension in the & Relaxed & $31(51 \%)$ & $61(100 \%)$ \\
head muscles* & Stuck in the shoulders & $30(49 \%)$ & 0 \\
Tension in the back ${ }^{*}$ & Relaxed & $18(29.5 \%)$ & $59(96.7 \%)$ \\
& Retracted & $43(70.5 \%)$ & $2(3.3 \%)$ \\
Pain complaint upon & Yes & $55(90.2 \%)$ & $22(36.1 \%)$ \\
discreet pinching* & No & $6(9.8 \%)$ & $39(63.9 \%)$ \\
\hline
\end{tabular}

* Statistically significant alteration $(p<0.05)$ 
As to muscle tension in the jawbones, we observed $23 \%$ of the patients who presented tight jawbones and who relaxed them during post-relaxation; the remaining $77 \%$ kept them relaxed in both the pre- and post-intervention phases.

Concerning muscle tension in the forearms, we observed $21.3 \%$ of the patients who presented slightly curved forearms in the pre-relaxation phase and who relaxed them in post-relaxation; the remaining $78.7 \%$ kept them relaxed in both the pre- and post-intervention phases.

Regarding muscle tension in the fists, we observed $11.5 \%$ of the patients who presented them almost closed in pre-relaxation and who relaxed them after the intervention; the remaining $88.5 \%$ kept them relaxed in both the pre- and post-relaxation phases.

The three variables mentioned above presented variations in the post-relaxation phase that were smaller than $25 \%$ (corresponding to 15 patients); therefore, it cannot be concluded that there were statistically significant alterations after the intervention. Although all the patients presented better conditions regarding muscle relaxation after it.

In relation to muscle tension in the head, we observed that $49 \%$ of the patients presented their heads stuck in the shoulders in pre-relaxation and relaxed in post relaxation; the remaining $51 \%$ kept them relaxed in both the pre- and post-relaxation phases. Considering the change rate (30 patients), it was shown to be statistically significant, that is, due to the relaxation intervention.

As to muscle tension in the back, we observed $67.2 \%$ of the patients who presented retracted muscles in pre-relaxation and relaxed muscles in post-relaxation; the remaining $29.5 \%$ kept it relaxed in both pre- and postrelaxation. We can equally assert that the alterations are statistically significant and a result of relaxation.

In relation to pain complaint due to minimum skin pinching, we observed $54.1 \%$ of the patients who presented such complaint in pre-relaxation and who confirmed its absence in post-relaxation; the remaining $36.1 \%$ kept such complaint in both pre- and post-relaxation and the other $9.8 \%$ did not show such complaint at any time. As to statistical testing, data show significant alteration.

The same was observed concerning perspiration; we observed $27.9 \%$ of the patients who presented excessive perspiration in pre-relaxation and normal perspiration in post-relaxation; the remaining $70.5 \%$ kept normal perspiration in both pre- and post-relaxation.
In this way, we concluded that there was significant change between pre- and post-relaxation situations for patients in all the types of muscle observation under analysis, among which muscle tension in the head, muscle tension in the back, pain upon pinching as well as perspiration were statistically significant as a result of Progressive Muscle Relaxation.

In relation to the intensity of the pain referred to by the patients by means of the visual pain scale in pre- and post- relaxation situations, the data are found in Table 4.

Table 4 - Distribution of pain scores expressed by the 61 patients in the pre- and post-relaxation phases

\begin{tabular}{|c|c|c|c|c|c|}
\hline $\begin{array}{l}\text { INDIVIDUAL } \\
\text { R }\end{array}$ & $\begin{array}{l}\text { LL PRE- } \\
\text { RELAXATION } \\
\text { (Var } 1)\end{array}$ & $\begin{array}{c}\text { POST- } \\
\text { RELAXATION } \\
\quad(\operatorname{Var} 2)\end{array}$ & INDIVIDUAL & $\begin{array}{c}\text { PRE- } \\
\text { RELAXATION } \\
\quad(\text { Var } 1)\end{array}$ & $\begin{array}{c}\text { POST- } \\
\text { RELAXATION } \\
\text { (Var 2) }\end{array}$ \\
\hline 1 & 3.5 & 0.0 & 32 & 4.5 & 0.5 \\
\hline 2 & 7.5 & 5.0 & 33 & 5.0 & 1.0 \\
\hline 3 & 3.0 & 1.5 & 34 & 5.0 & 1.5 \\
\hline 4 & 4.0 & 2.5 & 35 & 3.0 & 0.0 \\
\hline 5 & 3.5 & 1.5 & 36 & 4.0 & 0.0 \\
\hline 6 & 5.0 & 2.0 & 37 & 3.0 & 0.0 \\
\hline 7 & 4.0 & 1.5 & 38 & 6.0 & 2.5 \\
\hline 8 & 2.0 & 0.0 & 39 & 7.0 & 1.0 \\
\hline 9 & 3.5 & 0.5 & 40 & 6.0 & 2.0 \\
\hline 10 & 6.0 & 2.0 & 41 & 3.0 & 0.0 \\
\hline 11 & 8.0 & 4.0 & 42 & 2.5 & 0.0 \\
\hline 12 & 10.0 & 4.0 & 43 & 8.0 & 3.0 \\
\hline 13 & 3.0 & 1.0 & 44 & 4.5 & 1.5 \\
\hline 14 & 2.0 & 0.0 & 45 & 2.5 & 0.0 \\
\hline 15 & 4.5 & 2.0 & 46 & 2.0 & 0.0 \\
\hline 16 & 5.0 & 1.0 & 47 & 4.0 & 1.0 \\
\hline 17 & 2.0 & 0.5 & 48 & 2.0 & 0.0 \\
\hline 18 & 1.5 & 0.0 & 49 & 4.0 & 1.5 \\
\hline 19 & 2.5 & 0.5 & 50 & 5.0 & 2.0 \\
\hline 20 & 6.0 & 3.0 & 51 & 2.0 & 0.0 \\
\hline 21 & 2.0 & 0.0 & 52 & 1.5 & 0.0 \\
\hline 22 & 6.0 & 2.0 & 53 & 8.0 & 3.0 \\
\hline 23 & 4.5 & 3.0 & 54 & 4.0 & 1.5 \\
\hline 24 & 3.0 & 0.5 & 55 & 2.5 & 0.0 \\
\hline 25 & 4.5 & 1.5 & 56 & 5.0 & 0.5 \\
\hline 26 & 3.0 & 0.0 & 57 & 5.0 & 1.5 \\
\hline 27 & 4.0 & 0.5 & 58 & 2.0 & 0.0 \\
\hline 28 & 4.0 & 1.0 & 59 & 3.5 & 2.0 \\
\hline 29 & 5.0 & 1.0 & 60 & 2.0 & 0.5 \\
\hline 30 & 7.0 & 3.0 & 61 & 0.5 & 0.0 \\
\hline 31 & & 3.0 & & & \\
\hline
\end{tabular}

In order to analyze these data, we used the sign test and found a difference between the levels obtained in the two phases with a statistically significant reduction in pain level after relaxation $(z=7.68$ and $p \cong 0)$.

\section{CONCLUSIONS AND RECOMMENDATIONS}

In face of the results obtained, we observed a confirmation of the hypothesis that Progressive Muscle 
Relaxation causes the perception of pain relief as manifested by the patients. It is important to point out the possible effect of the researcher's interference with the obtained data during the application of the relaxation technique.

In this way, we encourage health care teams to prepare for the application of the progressive Muscle Relaxation technique in case of post-surgery pain complaints, which will certainly bring positive results to patients. We also suggest that patients be taught the self-

\section{REFERENCES}

1. Gozzani JL. Controle da dor requer constante atualização dos profissionais. Prática Hospitalar 2000 julho/agosto; 2(10):25-7.

2. Pimenta CAM. Aspectos culturais, afetivos e terapêuticos relacionados à dor no câncer. [tese]. São Paulo (SP): Escola de Enfermagem/USP; 1995.

3. Brunner LS, Suddarth DS. Enfermagem médico-cirúrgica. $3^{\text {a }}$ ed. Rio de Janeiro (RJ): Interamericana; 1977.

4. Titlebaum HM. Relaxation. Holistic Nursing Practice 1988 May; 2(3):17-25.

5. Flaherty GG, Fitzpatric JJ. Relaxation technique to increase comfort level of postoperative patients: a preliminary study. Nursing Research 1978 Nov-Dec; 27(6):352-5.

6 . Wells $\mathrm{N}$. The effect of relaxation on postoperative muscle tension and pain. Nursing Research 1982 July-Aug; 31 (4):236-8.

7. Aiken LH, Henrichs TH. Systematic relaxation as a nursing intervention technique with open heart surgery patients. Nursing Research 1971; 20(3):212-6.

8. Rees BL. Effect of relaxation with guided imagery on anxiety, depression and self-esteem in primiparas. Journal of Holistic Nursing 1995 Sept; 13(3):255-67.

9. Rees BL. An exploratory study of the effectiveness of a relaxation with a guided imagery protocol. Journal of Holistic Nursing 1993 Sept; 11(3):271-6.

10. Jacobson E. Progressive relaxation: a physiological and clinical investigation of muscular states and their significance in psychological and medical practice. $3^{\text {rd }}$ ed. Chicago: University of Chicago Press; 1974.

11. Payne RA. Relaxation Techniques: a practical handbook for the health care professionals. New York (NY): Churchill Livingstone; 1995.

12. Polit DF, Hungler BF. Fundamentos de pesquisa em enfermagem. $3^{\mathrm{a}}$ ed. Porto Alegre (RS): Artes Médicas; 1995.

13. Geissmann P, Bousinger RD. Métodos de relaxação. $2^{a}$ ed. São Paulo (SP): Loyola; 1987.

14. Ferraz AEP. Busca de informações: uma estratégia de "coping". [dissertação]. Ribeirão Preto (SP): Escola de Enfermagem de Ribeirão Preto/USP; 1988.

15. Niskier A. LDB: a nova lei da educação: tudo sobre a lei de diretrizes e bases da educação nacional: uma visão crítica. $7^{a}$ ed. Rio de Janeiro (RJ): Consultor; 1996.

16. Pereira LV, Sousa FAEF. Estimação em categorias dos descritores da dor pós-operatória. Rev Latino-am Enfermagem 1998 outubro; 6(4):41-8. application of such technique for pain relief. However, it is important to remember that post-surgery pain is real and must always be considered by all members on the health team. All the patients who have been submitted to surgical procedures must have analgesics available in order to control and treat pain.

The authors suggest that studies with larger samples and specific groups of gynecological surgeries be conducted with the purpose to observe possible divergence in relation to the these findings.

17. Mazzo A, Rodrigues NCF, Nogueira MS. Dor - Como a equipe de enfermagem anota este sintoma? Proceedings of the $3^{\text {rd }}$ Sibracen; 1992 May 13-15; Ribeirão Preto; 2000.

18. Black JM, Matassarin-Jacobs E. Enfermagem médicocirúrgica de Luckmann e Sorensen: uma abordagem psicofisiológica. $4^{\text {a }}$ ed. Rio de Janeiro (RJ): Guanabara Koogan; 1996.

19. Hollander M, Wolf DA. A non parametric statistical method. New York (NY): John Wiley; 1973.

20. Siegel S. Estatística não-paramétrica para as ciências do comportamento. São Paulo (SP): McGraw-Hill; 1975.

21. Daniel WW. Applied non parametric statistics. Boston (MA): Houghton Miflin; 1978.

22. Mann PS. Introductory Statistics. $3^{\text {rd }}$ ed. New York (NY): John Wiley; 1998.

23. Amorim MHC. A Enfermagem e a Psiconeuroimunologia no câncer de mama. [tese]. Rio de Janeiro (RJ): Escola de Enfermagem Anna Nery/Universidade Federal do Rio de Janeiro; 1999. 